\title{
TRYPANOSOMA CRUZI AND EXPERIMENTAL CHAGAS' DISEASE: CHARACTERIZATION OF A STOCK ISOLATED FROM A PATIENT WITH ASSOCIATED DIGESTIVE AND CARDIAC FORM
}

\author{
E.C. Oliveira, M.M.A. Stefani, A.O. Luquetti, E.F. Vêncio, \\ M.A.R. Moreira, C. Souza and J.M. Rezende
}

\begin{abstract}
A new Trypanosoma cruzi stock isolated from a patient in the chronic phase of Chagas' disease with the digestive and cardiac form of the disease was characterized by experimental infection in isogenic, susceptible, A/Sn strain mice. Parasitemia curves showed up to $1.7 \times 10^{6}$ parasites $/ \mathrm{ml}$ and no mortality was observed up to 300 days post infection. Specific lgM was found in mice in the acute phase up to 40 days and also in the chronic phase. Ig $G$ antibodies were detected in the acute and chronic phase. Histopathology examination demonstrated myotropism to the digestive tract muscle layers and to the heart.
\end{abstract}

Key-words: Trypanosoma cruzi strain. Chagas'disease. Experimental infection. Serology. Histopathology.

Trypanosoma cruzi is an hemoflagellate protozoan that causes Chagas' disease which produces different clinical manifestations in humans. Many patients remain asymptomatic in the indeterminate form of the disease. Amongst those symptomatic patients who develop lesions 10-20 years after the infection, $20-30 \%$ present the cardiac form ${ }^{22}$ of the disease and around $7 \%$ have megaesophagus ${ }^{6}$. The prevalence of patients with megacolon is not clear up to now.

Besides the genetic variation of the human host, $T$. cruzi has demonstrated to present intraspecific variation ${ }^{12} 12$. Infective population of parasites may have marked differences in relation with tissue tropism, parasitemia, pathogenicity and virulence. This heterogeneity in the $T$. cruzi population may contribute to the different clinical manifestations observed in the human population ${ }^{3}$ 11. A possible link between unique characteristics of the parasite population and the clinical manifestation of the host has been searched for,

Laboratório de Pesquisa da Doença de Chagas, Departamentos de Parasitologia e de Imunologia/Instituto de Patologia Tropical e Saúde Pública; Departamentos de Patologia e de Clínica Médica, Faculdade de Medicina/Universidade Federal de Goiás, Goiânia, GO.

Address to: Dr. Alejandro O. Luquetti. Laboratório de Pesquisa da Doença de Chagas. Hospital das Clínicas. Caixa Postal 1031, 74001-970 Goiânia, GO.

Recebido para publicação em 09/07/92. after several studies ${ }^{71825}$. The heterogeneity of the parasite population could explain the predominance of certain clinical forms in different geographical regions ${ }^{21} 24$. However the extent to which the parasite population contributes to the clinical manifestations of the disease is not clear. Classification of $T$. cruzi strains has been based on various criteria such as virulence, pathogenicity, morphology, isoenzymes, tissue tropism, parasitemia, immune response of the host, antigenic composition and susceptibility to various chemotherapeutic compounds ${ }^{13}$.

The study summarizes results concerning experimental infection with a stock of $T$. cruzi isolated from a patient with the associated (cardiac and digestive) form of Chagas' disease. The experimental infection was assessed in terms of parasitemia, mortality, antibody production of the host and histopathological lesions.

\section{MATERIAL AND METHODS}

\section{Source of parasites}

Triatomine bugs from xenodiagnosis of A.R.O., 35 years old, from an endemic region (Pirenópolis, State of Goiás), clinically, serologically and parasitologically diagnosed to have Chagas' disease was employed as the source of parasites used. Clinical manifestations of the disease included chagasic 
Oliveira EC, Stefani MMA, Luqueti AO, Vêncio EF, Moreira MAR, Souza C, Rezende JM. Trypanosoma cruzi and experimental Chagas' disease: characterization of a stock isolated from a patient with associated digestive and cardiac form. Revista da Sociedade Brasileira de Medicina Tropical 26:25-33, jan-mar, 1993.

cardiopathy characterized on the EKG by right bundle branch block and anterior left bundle branch block. This patient had a normal chest X-ray and was radiologically classified to have megaesophagus (group III) and dolicomegacolon. Serological reactions for American trypanosomiasis were positive by indirect hemagglutination, indirect immunofluorescence, direct agglutination with 2mercaptoethanol and ELISA. The patient was submitted to xenodiagnosis employing 40 Triatoma infestans bugs. Thirty and sixty days after the bloodmeal 5 out of 34 bugs were demonstrated to be positive.

\section{Obtention of parasites}

Infective metacyclic trypomastigote forms were obtained by compression of the posterior gut of positive T. infestans bugs. A suspension of parasites diluted in saline solution was inoculated intraperitoneally into susceptible A/Sn mice (4-6 weeks old, both sex). After 4 reinoculations a high number of parasites was obtained and used both for the experiment and for cryopreservation with $10 \%$ FCS (Microbiologica, Rio de Janeiro), $10 \%$ glycerol (Merck, Rio de Janeiro) and completed with RPMI1640 (GIBCO, USA).

\section{Experimental infection}

Three groups of 7 male A/Sn mice, 4 to 6 weeks old, weighing between 13 and $18 \mathrm{~g}$ were used. $T$. cruzi trypomastigotes were obtained by bleeding infected mice by the retro-orbital sinus. Each group of animals was infected intraperitoneally (I.P.) with different inocula which were as follows: 1,000 forms/mouse in group I, 10,000 forms/mouse in group II and 100,000 forms/mouse in group III. Four animals in the same conditions inoculated with $0.2 \mathrm{ml}$ of saline I.P. were used as a control group.

\section{Parasitemia and mortality}

Daily examinations of parasitemia were performed up to 14 days of the infection and then each other day until negativation was observed. Parasites were counted according to the technique proposed by Brener ${ }^{2}$ which analises $5 \mu 1$ of infected blood under a coverslip of $22 \times 22 \mathrm{~mm}$ with $400 \mathrm{x}$ magnification. Mortality was checked daily.

\section{Serological profile}

Animals were bled by the retro-orbital sinus on days $5,10,15,20,30,40,50,60,90,120,150$, 180,210 and 300 post infection. Blood from at least 3 animals from each group was pooled and sera were tested by indirect immunofluorescence employing antimouse IgM (Cappel Laboratories, Cochranville, USA) conjugated with rhodamine and antimouse IgG (Pasteur Institute, Paris) conjugated with fluorescein. Sera were diluted from 1:5 up to 1:640 for IgM and from 1:20 up to 1:640 for IgG.

\section{Histopathological examinations}

One animal from each group was sacrificed on days $40,60,90,180,210,300$ and 420 (only one animal of group I) employing ether. Tissue samples were fixed with buffered formaldehyde $10 \%(\mathrm{v} / \mathrm{v})$, pH 7.0, cut into $4 \mu \mathrm{m}$ thick, stained by hematoxilineosin and analysed with magnifications of 20,40 and $100 \mathrm{x}$ whenever necessary. Under suspicion of fibrosis, trichromic Masson staining was employed for better identification. Analysis of tissues included the identification of parasites, intensity of parasitism and type of inflammatory reaction. The following organs and tissues were examined: liver, spleen, lymph nodes, lungs, kidneys, testis, epididymus, adrenal glands, fat tissue (mesentery), esophagus, stomach, small intestine and bowel, striated muscle and heart (the whole organ).

\section{RESULTS}

\section{Parasitemia and peak of infection}

Parasites were found in animals of group I (lowest inoculum) on the 10th day post infection; in group II (intermediate inoculum) there was one positive animal on the first day post infection; in group III (highest inoculum) all animals were positive on the first day post infection (Figure 1). A direct correlation was observed between the inoculum and peak of parasitemia: the highest the inoculum, the highest and earliest peak of parasitemia 
Oliveira EC, Stefani MMA, Luqueti AO, Vêncio EF, Moreira MAR, Souza C, Rezende JM. Trypanosoma cruzi and experimental Chagas' disease: characterization of a stock isolated from a patient with associated digestive and cardiac form. Revista da Sociedade Brasileira de Medicina Tropical 26:25-33, jan-mar, 1993.

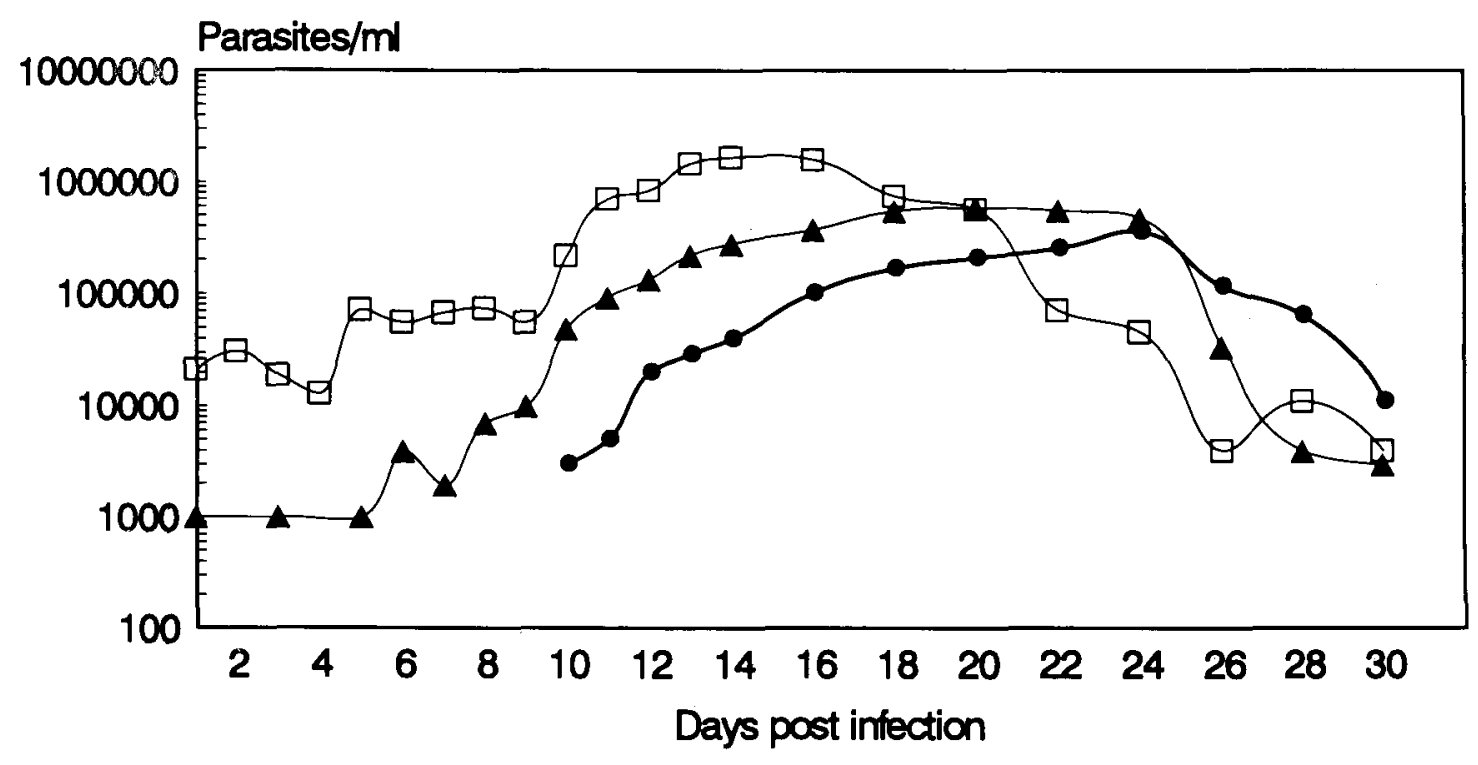

Incoula $=-1000 \star 10000 \boxminus 100000$

Figure 1 - Parasitemia curves with different inocula.

(group III $1.7 \times 10^{6}$ parasites $/ \mathrm{ml}$ on the day 14 th). A single peak was observed in each group. Peak of parasitemia in group II occurred on the 20th day post infection with $0.58 \times 10^{6}$ parasites $/ \mathrm{ml}$; in group I parasitemia peaked on the 24 th day with $0.35 \times 10^{6}$ parasites $/ \mathrm{ml}$. Following the peak there was negativation of the parasitemia which started on 24th day post infection in group II and III and on 28th day in animals from group I. Complete negativation was observed on the 46th and 50th day post infection in the animals infected with the intermediate and lowest inocula respectively. One animal belonging to the group of the highest inoculum remained positive up to 88 days post infection. There was no mortality during the acute phase. One animal from the group III and another from group II died on days 316 and 390 post infection, respectively. Control mice were alive up to 420 day when they were sacrificed and their organs examined.

\section{Serological profile}

Specific IgM antibodies were detected 5 days after infection in group I and II (titer 1/10). For the lowest inoculum they persisted through all the observation with peaks on days $15,30,90$ and 300 (Figure 2).

IgG antibodies were demonstrated earlier (30 days) in the group of highest inoculum - group III - (titer 1/20). The other groups (I and II) became positive after 50 days of infection (Figure 3 ) and remained positive for all samples tested.

\section{Histopathological examination}

Parasite pseudocysts were found in the heart, kidney, fat tissue and digestive tract in animals which were sacrificed up to 60 days after infection (Table 1). Heterogeneous patterns of reaction were observed amongst different organs and between different sections within a single organ examined.

Most proeminent inflammatory lesions were observed in the muscle layer of digestive tract (Figure 4). These alterations were of the same intensity along the esophagus, stomach, small and large intestine. Infiltrate was mostly lymphohistioplasmacytic however neutrophils and eosinophils were detected in certain areas. Inflammatory response was always in foci and not 
Oliveira EC, Stefani MMA, Luqueti AO, Vêncio EF, Moreira MAR, Souza C, Rezende JM. Trypanosoma cruzi and experimental Chagas' disease: characterization of a stock isolated from a patient with associated digestive and cardiac form. Revista da Sociedade Brasileira de Medicina Tropical 26:25-33, jan-mar, 1993.

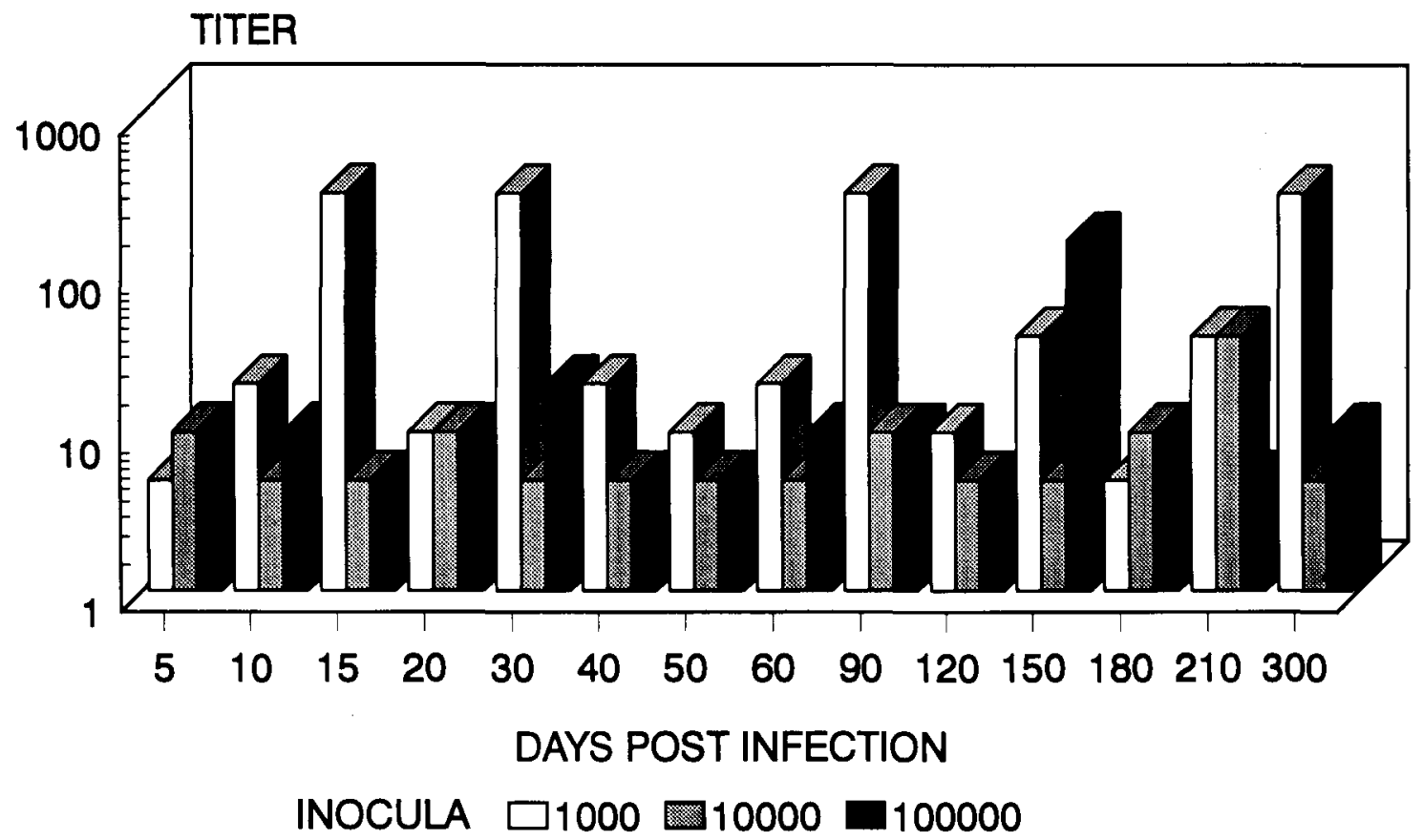

Figure 2 - IgM antibodies detected in the acute and chronic phase.



INOCULA $\square 1000 \square 10000 \square 100000$

Figure 3 - IgG antibodies: high levels in the chronic phase. 
Oliveira EC, Stefani MMA, Luqueti AO, Vêncio EF, Moreira MAR, Souza C, Rezende JM. Trypanosoma cruzi and experimental Chagas' disease: characterization of a stock isolated from a patient with associated digestive and cardiac form. Revista da Sociedade Brasileira de Medicina Tropical 26:25-33, jan-mar, 1993.

Table 1 - Inflamatory response and parasitemia.

\begin{tabular}{|c|c|c|c|c|c|c|c|c|c|c|c|c|c|}
\hline $\begin{array}{l}\text { Organ } \\
\text { days/inoc }\end{array}$ & Heart & $\begin{array}{c}\text { Striat } \\
\text { muscle }\end{array}$ & Tongue & $\begin{array}{c}\text { Eso- } \\
\text { phagus }\end{array}$ & Stomach & $\begin{array}{l}\text { Small } \\
\text { intest. }\end{array}$ & Colon & Kidney & $\begin{array}{c}\text { Fat } \\
\text { tissue }\end{array}$ & $\begin{array}{c}\text { Liver } \\
\text { Kupffer } \\
\text { cells }\end{array}$ & $\begin{array}{c}\text { Spleen } \\
\text { plasma } \\
\text { cells }\end{array}$ & Lungs & $\begin{array}{c}\text { L.node } \\
\text { plasma } \\
\text { cells }\end{array}$ \\
\hline
\end{tabular}

$\begin{array}{rcccccc}40 \mathrm{~d} 10^{3} & +++ & + & - & +++ & +++ & + \\ & \text { PP } & & & \text { PPP } & \text { PPP } & \\ 10^{4} & \begin{array}{c}+ \\ \end{array} & + & - & - & - & - \\ 10^{\text {PPP }} & +++ & - & - & + & - & +\end{array}$

\begin{tabular}{|c|c|c|c|c|c|c|c|c|c|c|c|c|}
\hline $60 \mathrm{~d} 10^{3}$ & + & - & - & + & + & $+t$ & ++ & & +++ & + & + & - \\
\hline $10^{4}$ & ++ & ++ & - & ++ & - & $+t$ & ++ & - & - & + & + & - \\
\hline $10^{5}$ & +++ & + & - & + & - & $\begin{array}{c}+ \\
\text { PP }\end{array}$ & - & $\mathbf{P}$ & $\begin{array}{c}+ \\
\text { PPP }\end{array}$ & - & - & - \\
\hline
\end{tabular}

\begin{tabular}{|c|c|c|c|c|c|c|c|c|c|c|c|c|}
\hline $90 \mathrm{~d} 10^{3}$ & + & + & - & - & - & + & +++ & - & +++ & - & - & - \\
\hline $10^{4}$ & ++ & + & - & + & - & + & + & - & + & +++ & - & - \\
\hline $10^{5}$ & $\begin{array}{c}++ \\
F\end{array}$ & + & + & +++ & +++ & +++ & +++ & - & + & - & - & + \\
\hline
\end{tabular}

$\begin{array}{rrrrrrrr}180 \mathrm{~d} 10^{3} & + & + & ++ & +++ & +++ & +++ & +++ \\ & \mathrm{F} & & & & + & & + \\ 10^{4} & + & ++ & + & - & - & + & + \\ 10^{5} & ++ & + & + & + & - & + & +\end{array}$

\begin{tabular}{|c|c|c|c|c|c|c|c|c|c|c|}
\hline $210 \mathrm{~d} 10^{3}$ & $\begin{array}{l}+ \\
F\end{array}$ & + & + & - & - & +++ & +++ & + & + & +++ \\
\hline $10^{4}$ & $\begin{array}{c}++ \\
F\end{array}$ & + & - & - & - & +++ & +++ & - & + & $++t$ \\
\hline $10^{5}$ & +++ & - & - & - & - & $+t+$ & +++ & - & +++ & +++ \\
\hline $10^{3}$ & + & + & - & + & + & ++ & ++ & - & ++ & + \\
\hline $300 \mathrm{~d} 10^{4}$ & + & + & - & + & + & ++ & ++ & - & + & + \\
\hline $10^{5}$ & + & + & - & + & + & + & + & - & ++ & + \\
\hline
\end{tabular}

$420 \mathrm{~d} 10^{3}$

$+\quad++\quad+\quad++\quad-\quad+$

Inoc = inoculum; L. node = Lymph node;

Inflammation: + slight; ++ moderate; +++ sereve; $\mathbf{F}=$ fibrosis.

Parasite pseudocysts: P slight; PP moderate; PPP severe. 
Oliveira EC, Stefani MMA, Luqueti AO, Vêncio EF, Moreira MAR, Souza C, Rezende JM. Trypanosoma cruzi and experimental Chagas' disease: characterization of a stock isolated from a patient with associated digestive and cardiac form. Revista da Sociedade Brasileira de Medicina Tropical 26:25-33, jan-mar, 1993.

in difuse aspect either in the striated and heart muscles or in the walls of the hollow organs. Even where the inflammation was considered severe it had an uneven distribution having segments without any infiltration.

An increase of plasma cells was observed both in the lymph nodes and spleen. An inflammatory infiltrate ranging from slight to marked was observed in the fat tissue of all groups.

Hyperplasia of Kupffer cells with variable intensity was observed in all groups.

In spite of exhaustive search no parasites were observed in the spleen or adrenal glands.

The inflammatory infiltrate in the heart was mostly observed in the epicardium and endocardium (Figure 5). Besides the infiltrate, focal areas of necrosis were observed both in the cardiac and skeletal muscle. Discreet foci of fibrosis were observed in the animals sacrificed between 180 and 210 days (Table 1 ).

\section{DISCUSSION}

The $T$. cruzi strain studied was of low virulence even with the highest inoculum, since no mortality was observed up to 300 days post infection. Concerning parasitemia a direct relationship was observed between inoculum, onset of parasitemia and its peak. The presence of bloodstream forms $24 \mathrm{~h}$ after infection could be due to non-penetrating parasites. Brener ${ }^{2}$ reported 5 strains ( 2 isolated from chagasic patients) with bloodstream forms $24 \mathrm{~h}$ post infection using a inoculum of $0.15 \times 10^{6}$ forms. The parasitemia profile observed in this study was similar to parasitemia curves obtained with other stocks of $T$. cruzi recently isolated from chronic chagasic patients 15162526 .

Immunological response was demonstrated 5 days after inoculation, by detectable levels of specific IgM antibodies which increased progressively afterwards until 30 days. IgG antibodies were present by day 30 after infection in the group with the highect and 50 days post infection in animals with the intermediate and lowest inocula.

An unexpected result was obtained in relation to the presence of detectable IgM in mice during the chronic phase of the disease. Besides the fact that they were present in all groups of mice, they persisted throughout the time studied. Lana et $a^{8}$ using dogs reported $\operatorname{IgM}$ in the chronic phase with decreasing titers from 3 to 9 months after infection; Peralta et $\mathbf{l}^{20}$ using mice reported only specific IgG but not IgM during the chronic phase. According to our data, high levels of IgM were found later, in the chronic phase (10 months after infection) and titers did not decrease afterwards. Magnani et al ${ }^{9}$ reported $\operatorname{IgM}, \operatorname{IgA}$ and $\operatorname{IgG}$ in the chronic phase of human disease. These data were not confirmed by studies performed by Rassi et $\mathrm{al}^{23}$ and by Camargo and Amato Neto ${ }^{4}$ who did not find $\operatorname{IgM}$ in sera from chronic patients even with persitent positive xenodiagnosis. The presence of IgM in our infected animals may be characteristic of some strains. In support of this view a similar finding with the experimental infection of another stock $^{5}$ was observed. The interpretation of these data which were not reported in mice before, remains to be elucidated.

A clear miotropism to skeletal and smooth muscle was shown by the histopathological examination. The heart and digestive tract had the most severe inflammatory reaction independently of inoculum size. Even injecting mice with an inoculum a hundred times higher we had the same inflammatory reaction. According to previous reports ${ }^{1926}$ our findings confirm that inflammatory reaction and fibrosis are related to the pathogenicity of strains. Despite the inflammation no dilatation was observed in the digestive tube according to macroscopic examination. Okumura et al ${ }^{14}$ reported chronic chagasic mice with megacolon and Petana et al $^{17}$ reported 2 mice with megacolon infected with stocks from natural reservoirs. Marsden et al ${ }^{10}$ reported gastric dilatation in mice infected with stocks from patients with megaesophagus. Also the origin of the strain, from naturally infected animals or humans, may influence the parasite tropism and pathogenicity of experimental animals.

This stock may be classified as belonging to type II according to Andrade's parameters ${ }^{1}$ of strain classification because of the low virulence and mortality with heart tropism. On the other hand, mortality pattern of type II strains is usually higher than the stock here described, with deaths within the first month after infection; hence, by mortality criteria, this stock could be classified as type III. Another fact that favours this stock as type III is the presence of severe intestinal lesions a fact which is 
Oliveira EC, Stefani MMA, Luqueti AO, Vêncio EF, Moreira MAR, Souza C, Rezende JM. Trypanosoma cruzi and experimental Chagas' disease: characterization of a stock isolated from a patient with associated digestive and cardiac form. Revista da Sociedade Brasileira de Medicina Tropical 26:25-33, jan-mar, 1993.
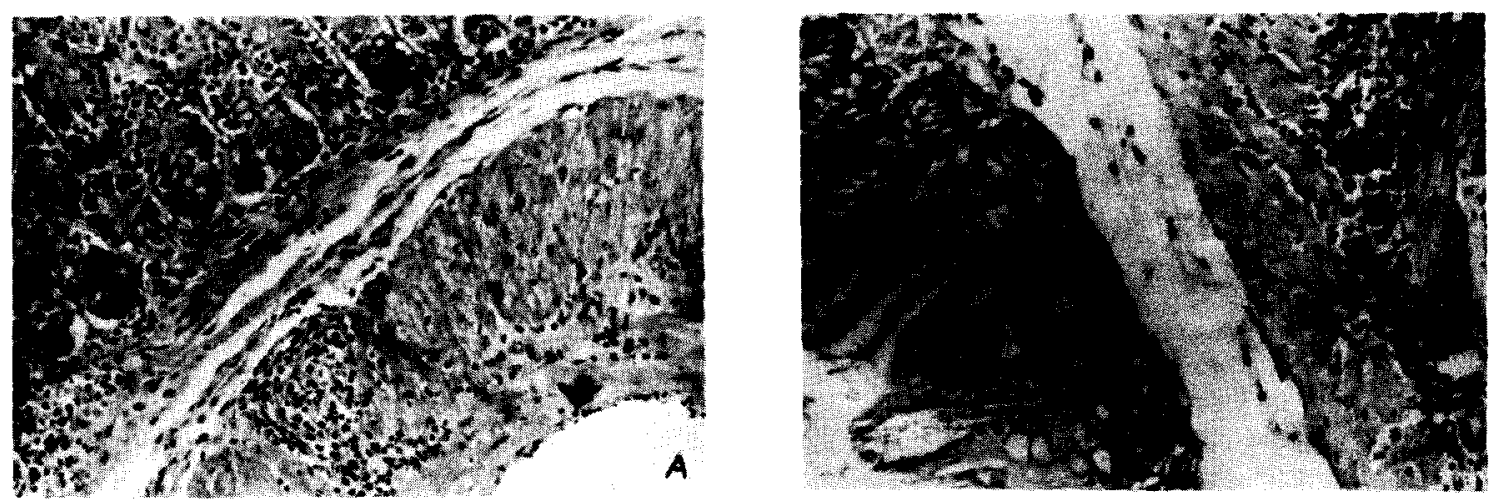

Figure 4-Photomicrographs of small (A) and large (B) intestine in the chronic phase: severe hympho-histiocytic infiltrate mainly in muscle and serosa layers (HE) (100x).
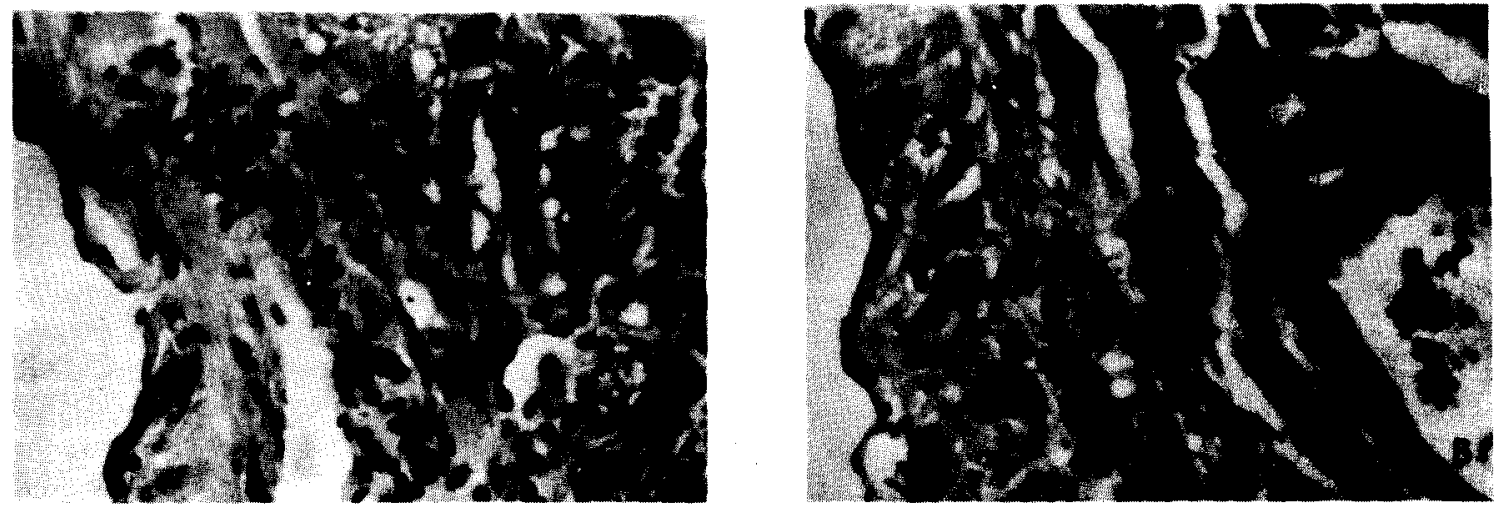

Figure 5 - Photomicrographs of heart $(A$ and $B)$ in the chronic phase: endocardic and myocardial tympho-histiocytic infiltrate foci (HE) (200x).



Figure 6 - Photomicrograph of intestine wall: intrinsic nervous system cells (arrow) (HE) (400x). not described in type II strains.

A larger group of stocks isolated from the same region and from patients with well characterized clinical forms may provide further information in relation with the pathogenesis of Chagas' disease.

\section{RESUMO}

Um novo estoque de Trypanosoma cruzi isolado de paciente chagásico crônico, com a forma digestiva $e$ cardiaca da doença, foi caracterizado através de infecção experimental em camundongos isogênicos $A / S n$ suscetiveis à infeç̧ão chagásica. As curvas de parasitemia mostraram picos de até $1,7 \times 10^{6}$ parasitas $/ \mathrm{ml}$ não se observando 
Oliveira EC, Stefani MMA, Luqueti AO, Véncio EF, Moreira MAR, Souza C, Rezende JM. Trypanosoma cruzi and experimental Chagas' disease: characterization of a stock isolated from a patient with associated digestive and cardiac form. Revista da Sociedade Brasileira de Medicina Tropical 26:25-33, jan-mar, 1993.

mortalidade até 300 dias pós infecção. Anticorpos da classe IgM foram encontrados na fase aguda até 40 dias e também na fase crônica e $\operatorname{Ig} G$ foi detectada nas fases aguda e crônica. $O$ exame histopatológico mostrou miotropismo para músculo liso do tubo digestivo e cardiaco.

Palavras-chaves: Cepa de Trypanosoma cruzi. Doença de Chagas. Infecção experimental. Sorologia. Histopatologia.

\section{REFERENCES}

1. Andrade SG. Caracterização de cepás do Trypanosoma cruzi isoladas no recôncavo baiano. Revista de Patologia Tropical 3:65-121, 1974.

2. Brener $Z$. Comparative studies of different strains of Trypanosoma cruzi. Annals of Tropical Medicine and Parasitology 59:19-26, 1964.

3. Brener $Z$. Recent developments in the field of Chagas' disease. Bulletin of the World Health Organization 60:463-473, 1982.

4. Camargo ME, Amato Neto A. Anti-Trypanosoma cruzi IgM antibodies as serological evidence of recent infection. Revista do Instituto de Medicina Tropical de São Paulo 16:200-202, 1974.

5. Castro AM, Oliveira EC, Stefani MMA, Rezendc $\mathrm{JM}$, Luquetti $\mathrm{AO}$. Relación entre número de parásitos $y$ respuesta inmune humoral en ratones infectados con dos estoques aislados de pacientes chagásicos. $\mathrm{X}$ Congreso Latinoamericano de Parasitologia. Montevideo, novembro, 1991.

6. Castro C, Rezende JM, Camargo M, Cerisola A. Prata A, Macedo V. Esofagopatia chagásica no município de Mambaí. Revista da Sociedade Brasileira de Medicina Tropical 17(sup1):22, 1984.

7. Kipnis TL, Minoprio PM, Luquetti AO, Rassi A, Dias WD. Estudo imunobiológico äe estoques de Trypanosoma cruzi isolados de pacientes na fase aguda da doença de Chagas. Revista da Sociedade Brasileira de Medicina Tropical 16:175-183, 1983.

8. Lana M, Vieira LM, Lemos EM, Tafuri WL, Chiari E, Costa CA. Perfil de IgG e IgM em cães experimentalmente infectados por Trypanosoma cruzi durante a fase aguda e crônica da infecção. Revista da Sociedade Brasileira de Medicina Tropical 22(supl. II):78, 1989.

9. Magnani MAC, Ferriolli Filho F, Siqueira AF. Imunoglobulinas (IgA, IgG e IgM) em soros de chagásicos crônicos verificados por reações de imunofluorescência indireta. Revista do Institute de Medicino Tropical de São Paulo 15:72-75, 1973.

10. Marsden PD, Alvarenga NJ, Soares VA, Gaina MP. Attempts to produce megasyndrome in mice using stocks of Trypanosoma cruzi with megaesophagus in man. Transactions of the Royal Society of Tropical Medicine and Hygiene 73:651-655, 1979.

11. Miles MA. Transmission cycles and the heterogeneity of Trypanosoma cruzi . In: Lumsden WHR, Evans DA (ed) Biology of the Kinetoplastida. Academic Press, London, vol. 2 p.117-196, 1979.

12. Miles MA, Cibulskis RE. Zymodeme characterization of Trypanosoma cruzi. Parasitology Today 2:94-97, 1986.

13. Nussensweig V, Deane LM, Kloetzel J. Diversidade na constituição antigênica de amostras de Trypanosoma cruzi isoladas do homem e de gambás. Revista do Instituto de Medicina Tropical de São Paulo 4:409-910, 1962.

14. Okumura M, Fonseca LC, Correa Neto A. A patologia da doença de Chagas experimental em camundongos brancos. Revista do Hospital das Clínicas 18:73-78, 1963.

15. Oliveira EC, Vêncio EF, Araújo MM, Silva IG, Rezende JM, Luquetti AO. Curva de parasitemia de estoque de Trypanosoma cruzi proveniente de paciente com a fase crônica da Doença de Chagas. In: Resumos da V Reunião Anual de Pesquisa Aplicada em Doença de Chagas, Araxá p.69, 1988.

16. Oliveira EC, Vêncio EF, Araújo Jr UG, Bechepeche MAF, Silva IG, Vaz MGM, Rezende JM, Luquetti AO. Comportamento em animais de estoque de Trypanosoma cruzi isolado de paciente na forma digestiva da doença de Chagas. In: Resumos do XXVI Congresso da Sociedade Brasileira de Medicina Tropical, Natal p.149, 1990.

17. Petana WB, Coura JR. Experimental studies on Trypanosoma (Schizotrypanum) cruzi strains isolated from man, from animals and from triatomine bugs in Brazil. Revista da Sociedade Brasileira de Medicina Tropical 8:315-323, 1974.

18. Ponstam M, MacDaniel JP, Dvorak JA. Trypanosoma cruzi: constancy of clone pathogenicity for inbred mice during long-term in vitro maintenance. Transactions of the Royal Society of Tropical Medicine and Hygiene 80:659-663, 1986.

19. Ponstan M, MacDaniel JP, Dvorak JA. Comparative studies of the infection of Lewis rats with four Trypanosoma cruzi clones. Transactions of the Royal Society of Tropical Medicine and Hygiene 81:415-419, 1987.

20. Peralta JM, Filardi L, Lourdes MAL, Torres ST. Trypanosoma cruz $i$ antibodies in mice infected with different strains of $T$. cruzi. Journal of Parasitology 66:342-344, 1980.

21. Prata A. Natural history of chagasic cardiomyopathy. In: New approaches in American Trypanosomiasis Research. Pan American Health Organization Scientific Publication 318. Washington p.191-193, 
Oliveira EC, Stefani MMA, Luqueti AO, Vêncio EF, Moreira MAR, Souza C, Rezende JM. Trypanosoma cruzi and experimental Chagas' disease: characterization of a stock isolated from a patient with associated digestive and cardiac form. Revista da Sociedade Brasileira de Medicina Tropical 26:25-33, jan-mar, 1993.

1976.

22. Prata A. Significance of Trypanosoma cruzi differentiation and selection, relationship with clinical and epidemiological varieties. Revista da Sociedade Brasileira de Medicina Tropical 18(supl):9-16, 1985.

23. Rassi A, Amato Neto V, Lemos ZP, Almeida JWR. Tentativa de correlação entre parasitemia, avaliada por xenodiagnóstico, e pesquisa de anticorpos IgM antitripanosoma no soro de pacientes na fase crônica da doença de Chagas. Revista Goiana de Medicina 24:67-75, 1978.

24. Rezende JM. Chagasic mega syndromes and regional differences. In: New Approaches in American Trypanosomiasis Research. Pan American Health
Organization Scientific Publication 318. Washington p.195-205, 1976.

25. Schlemper Jr BR. Caracterização de cepas de Trypanosoma cruzi isoladas de pacientes com diferentes formas clínicas da doença de Chagas. Tese de doutorado, Universidade Federal do Rio de Janeiro, Rio de Janeiro, 1982.

26. Schlemper Jr BR, Avila CM, Coura JR, Brener Z. Course of infection and histopathological lesions in mice infected with seventeen Trypanosoma cruzi strains isolated from chronic patients. Revista da Sociedade Brasileira de Medicina Tropical 16:2330, 1983. 